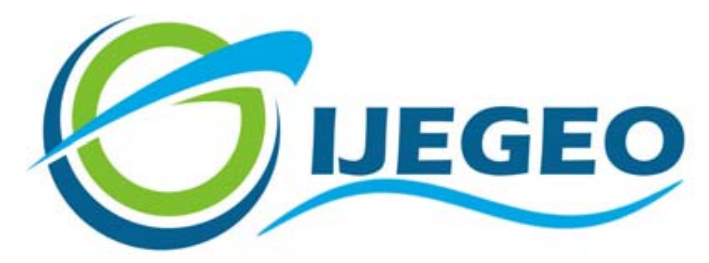

International Journal of Environment and Geoinformatics (IJEGEO) is an international, multidisciplinary, peer reviewed, open access journal.

\title{
Investigating the Reliability of Irrigated Area Coverages from Fragmented Lands: The case of Tigray, Northern Ethiopia
}

\section{Filmon Tquabo GEBREMARIAM, Solomon HABTU, Yemane ADANE, Tesfa-alem GEBREEGZIABHER, Negasi SOLOMON, Eyasu YAZEW}

\author{
Chief in Editor \\ Prof. Dr. Cem Gazioğlu \\ Co-Editors \\ Prof. Dr. Dursun Zafer Şeker, Prof. Dr. Şinasi Kaya, \\ Prof. Dr. Ayşegül Tanık and Assist. Prof. Dr. Volkan Demir
}

Editorial Committee (August 2020)

Assos. Prof. Dr. Abdullah Aksu (TR), Assit. Prof. Dr. Uğur Algancı (TR), Prof. Dr. Bedri Alpar (TR), Prof. Dr. Lale Balas (TR), Prof. Dr. Levent Bat (TR), Prof. Dr. Paul Bates (UK), İrşad Bayırhan (TR), Prof. Dr. Bülent Bayram (TR), Prof. Dr. Luis M. Botana (ES), Assos. Prof. Dr. Gürcan Büyüksalih (TR), Prof. Dr. Nuray Çağlar (TR), Prof. Dr. Sukanta Dash (IN), Dr. Soofia T. Elias (UK), Prof. Dr. A. Evren Erginal (TR), Assoc. Prof. Dr. Cüneyt Erenoğlu (TR), Dr. Dieter Fritsch (DE), Prof. Dr. Çiğdem Göksel (TR), Prof.Dr. Lena Halounova (CZ), Prof. Dr. Manik Kalubarme (IN), Dr. Hakan Kaya (TR), Assist. Prof. Dr. Serkan Kükrer (TR), Assoc. Prof. Dr. Maged Marghany (MY), Prof. Dr. Michael Meadows (ZA), Prof. Dr. Nebiye Musaoğlu (TR), Prof. Dr. Masafumi Nakagawa (JP), Prof. Dr. Hasan Özdemir (TR), Prof. Dr. Chryssy Potsiou (GR), Prof. Dr. Erol Sarı (TR), Prof. Dr. Maria Paradiso (IT), Prof. Dr. Petros Patias (GR), Prof. Dr. Elif Sertel (TR), Prof. Dr. Nüket Sivri (TR), Prof. Dr. Füsun Balık Şanlı (TR), Prof. Dr. Uğur Şanlı (TR), Duygu Ülker (TR), Prof. Dr. Seyfettin Taş (TR), Assoc. Prof. Dr. Ömer Suat Taşkın (US), Dr. İnese Varna (LV), Dr. Petra Visser (NL), Prof. Dr. Selma Ünlü (TR), Assoc. Prof. Dr. İ. Noyan Yılmaz (AU), Prof. Dr. Murat Yakar (TR), Assit. Prof. Dr. Sibel Zeki (TR) 
Reaserch Article

\title{
Investigating the Reliability of Irrigated Area Coverages from Fragmented Lands: The case of Tigray, Northern Ethiopia
}

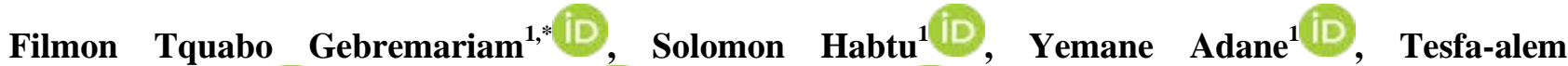 \\ Gebreegziabher $^{2}$ iD, Negasi Solomon ${ }^{1}$, Eyasu Yazew ${ }^{1,2}$ iD
}

${ }^{1}$ Department of Land Resources Management and Environmental Protection, Mekelle University, P.O. Box 231, Mekelle, Ethiopia.

${ }^{2}$ Institute of Water and Environment, Mekelle University, P.O. Box 231, Mekelle, Ethiopia.

* Corresponding author:FT. Gebremariam

E-mail: fillmon.tquabo@gmail.com

Received 05 Dec 2019

Accepted 01 May 2020

How to cite: Gebremariam, et al., (2020). Investigating the Reliability of Irrigated Area Coverages from Fragmented Lands: The case of

Tigray, Northern Ethiopia. International Journal of Environment and Geoinformatics (IJEGEO), 7(2), 172-183. DOI: 10.30897/ijegeo.655595

\begin{abstract}
Consistent and well-timed information regarding the extent of irrigated areas is very important for the development of the agricultural sector. This study investigated the reliability of traditional estimates of irrigated area coverages from three micro-dam irrigation schemes. High resolution Google Earth (GE) and medium resolution satellite imagery coupled with an intensive ground survey were employed to determine irrigation area coverages. LANDSAT-8 image pre-processing and classification was carried out in Environment for Visualizing Images (ENVI 5.0) software. In comparison to the LANDSAT-8 based estimates, the traditional method over-estimated $87 \%$ of the total 14 cases considered. The level of discrepancies in scheme area coverages range from a minimum of $20 \%$ (underestimated) to a maximum of $224 \%$. Besides this, the traditional estimates were ranging from -1.8 to $238 \%$ of GE-based estimates. Whereas, the LANDSAT- 8 based estimates slightly overestimated it by $1.8 \%-16 \%$ of GE-based estimates. On the other hand, the traditional estimates tend to underestimate/ignore crops with smaller area coverages and overestimate crops with relatively larger area coverages. The results hinted that the using medium and low resolution satellite imagery could improve the data collection and reporting from irrigated agriculture in developing countries.
\end{abstract}

Keywords: Irrigated area, LANDSAT-8, Remote sensing, Ethiopia

\section{Introduction}

The Ethiopian economy is highly dependent on the agricultural sector which contributes to nearly $41 \%$ of the Gross Domestic Product (GDP) (MOFED, 2010). As a result, agriculture is considered as one of the main pillars for sustaining and flourishing the national economy (CSA, 2018). During the five years of the Growth and Transformation Plan (GTP) of Ethiopia which was implemented from 2010/2011 to 2014/2015, Ethiopia has had an "impressive" track record of growth and poverty reduction, with GDP growing by an average of $10.1 \%$ (IMF, 2016). However, the issue of ensuring food security and equitable distribution of wealth remains a challenge for the future. Moreover, the agricultural sector, dependent on rainfall with an unreliable and erratic nature (Bewket and Conway, 2007), is facing challenges of climate change coupled with an increasing population growth. In the years from 2000 to 2016, the population increased from 61.5 to 102.4 million with an average annual growth rate of 2.7\% (World_Bank, 2017). In the period from 1950 till 1996, Ethiopia was hit by 13 events of droughts (FAO, 1996), not to mention the recent drought which occurred in 2009 (Addis, 2009; Ülker et al., 2018; Kedirgan, 2019) and droughts occurred in the aftermath of the 2016 El Nino effect (Gleixner et al., 2017). Hence, supplementing the rain-fed agricultural system by irrigation development has paramount significance in attaining food security and creating a buoyant economy at large. Besides, having accurate and timely information regarding irrigated agriculture is equally important.

However, despite the vital significance of agriculture to national economies of many countries, there is a persistent weakness in the way data is collected and reported from smallholder farmers in Sub-Saharan countries (Carletto et al., 2013). The total cultivated land in Ethiopia in 2014 was estimated to be 16 million hectares out of which, only $5 \%$ are "equipped for irrigation" in 2015 (AQUASTAT, 2015). An area which is "equipped for irrigation" refers to a land having access to irrigation infrastructure, irrespective of the presence of other inputs such as sufficient and acceptable quality water source, fertile soil, and other environmental settings (FAO, 2012; İmamoğlu and Sertel, 2016). These factors are subject to temporal and spatial variation from one irrigation season to the other. This implies that an area which is equipped for irrigation may not be actually irrigated every year. However, as indicated in FAO (2012), in many African countries including Ethiopia, there is a trend of reporting an area equipped with irrigation infrastructure to be $100 \%$ of the actual irrigated area. Such generalizations mostly over-estimate the extent of the actual irrigated area. Moreover, it may 
have a misleading effect on the Gross Domestic Product (GDP) and economic indicators of the country.

Consistent and well-timed information regarding the extent of irrigated areas is very important for the development of the agricultural sector in particular and overall economy in general. In most of the developing world, information from irrigated areas is gathered through traditional methods such as ground-based census, visual estimation, and other primitive methods of data collection and reporting. Mostly, these methods have the benefit of getting hands-on information regarding irrigated area coverage and other agricultural production attributes. Nevertheless, in many cases, such information is likely to witness discrepancies when compared with the actual area of irrigated lands. Some of the causes of discrepancies are related to mistakes and errors in estimating and recording which are to some extent attributable to the lack of skill among experts, and poor data collection and reporting methodologies (Carletto et al., 2013; Nickum, 2003). For example, out of 44 sub-Saharan African countries evaluated, only two were found to have high standards in collecting agricultural data (FAO, 2008).

According to Awulachew et al. (2007), there is a wide range of agricultural data reliability and consistency flaws specifically from irrigated agriculture in Ethiopia. The magnitude and severity of data discrepancies regarding irrigated area coverages could vary from country to country. In countries like Ethiopia, farmerlevel irrigated lands are highly fragmented, usually not exceeding 0.5 hectares per farmer (Gebregziabher et al., 2012). Therefore, in such highly fragmented schemes, the effect of such discrepancies could be highly magnified. According to Mandefro (2016) data figures depicting agricultural attributes, poverty reductions, and other statistical reports are becoming tools and indicators of an ongoing power struggle in Ethiopia.

Many studies have been conducted on to compare the remote sensing estimates with agricultural census data. Pandey and Seto (2015) compared remote sensing estimates and agricultural census of India and witnessed inconsistencies between the two approaches. Another study by Biggs et al. (2006) tried to compare irrigated area maps of different datasets (i.e. Moderate Resolution Imaging Spectrometer (MODIS), ground truth data, agricultural census and LANDSAT TM) and obtained wide-ranging agreements. Again, Ajaz et al. (2016) compared remote sensing estimates against national and international census of 10 Asian countries and found variations extending from minimum of $64 \%$ in Indonesia to a maximum of $129 \%$ for India. Yet in some other studies, without being aware of the possible inconsistencies associated with it, agricultural census is considered as a baseline data for evaluating other irrigated area estimates (Ambika et al., 2016; Gumma et al., 2015). However, the traditional estimates of irrigated areas in the developing world are prone to significant data inconsistencies (Frolking et al., 1999; Giordano, 2009; Nickum, 2003; Thenkabail et al., 2009). So far, the literature regarding the studies investigating the reliability of agricultural census are so scarce.

With the emergence of remotely sensed images and geographic information systems, spatial information analysis has ever become an economical, simpler and more useful way of estimating coverages of irrigated croplands (Cai et al., 2017; Heller et al., 2012; Murthy Reddi et al., 2017; Ozdogan et al., 2010). Using highresolution satellite images, it was made possible to digitize very small parcels of land and use these digitized maps along with GPS locations to estimate the area with appreciable accuracies (Jacobson et al., 2015). Satellite Imagery has also made it possible to understand the historical trends of coverage in an irrigation scheme. Therefore, this research employed medium (LANDSAT8 ) and fine resolution (Google Earth Pro®) satellite imagery to compare the traditional estimates with the remotely sensed estimates for three micro-dam irrigation schemes in Northern Ethiopia.

\section{Materials and Methods}

\section{Description of the Study Sites}

The three representative micro-dam irrigation schemes; namely Haiba, May-Nigus, and Shilanat-2 are located in Tigray regional state, Northern Ethiopia. Their geographic locations and other salient features are summarized in Figure 1 and Table 1. The topography of Tigray region is largely characterized by mountain plateaus intermingled with small valley plains situated in the lowlands. The climate of the region is mainly semiarid with the majority rainfall, constituting around $80 \%$, occurring in three to four months (June, July, August, and/or September) of the year (Eyasu, 2005).

The three schemes exhibit similar soil, land use/cover and topographic characteristics. The soil type in the May-Nigus command area s dominantly silt loam with limited presence of clay soils. The land use types in watershed are mainly cultivated, grazing land and sparse woodlands. The slope of the watershed is dominated by steep highlands in the northern, eastern and western parts and gentle slopes in the southern and central parts of the watershed (Nata et al., 2010).

The majority of soil in the command area of Shilanat-2 watershed is sandy loam (nearly 60\%) with sparse coverage of loam and loamy sand soils. The land use coverage is dominated by cultivated land followed by grazing and forest lands (Filmon, 2013). On the other hand, the slope in the Haiba watershed is characterized by flat terrain and surrounding hills and mountain tops in the southeastern and northern boundaries. The land use /cover in Haiba watershed is mainly cultivated land, grazing land (Behailu et al., 2004).

The most common economic activities in the rural parts Tigray region are farming, animal rearing, poultry farming, masonry and daily labor. However, In the last few decades, irrigation schemes developments have led to increased farm incomes for rural households. 
Table 1. Salient features about the study sites

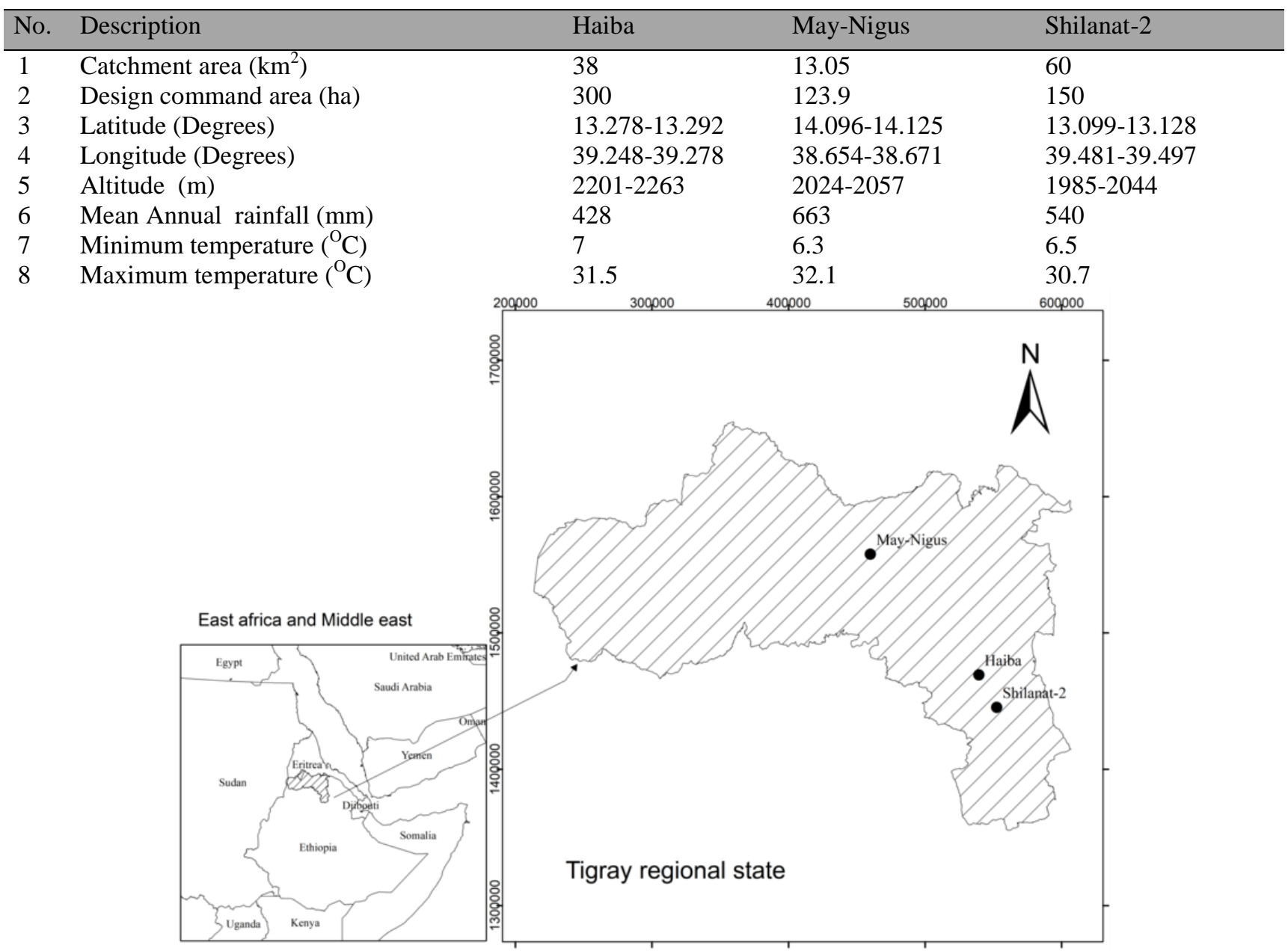

Fig. 1. Location of study sites

\section{Data Collection}

\section{Irrigated Area Coverages Acquired using Traditional Methods}

Currently, total irrigation coverages of a scheme and crop-specific area figures are collected at Kebelle level (Kebelle is the smallest administrative unit within the Ethiopian government's administration hierarchy). The development agents (DAs) at Kebelle level collect the information via a couple of traditional methods. In some schemes, they estimate visually or seek information from the Water User Associations (WUAs) about the areal extent of each irrigated crop and the total irrigated area. Recently, Global Positioning System (GPS) is helping to assist the estimation process. For this study, irrigation coverage data acquired using the traditional method for consecutive five-year irrigation seasons (2013 to 2017) were obtained from Kebelle level Agriculture and Rural Development (ARD) offices of each study site.

\section{Google Earth (GE) Based Ground Survey}

An extensive field survey was conducted on the three irrigation schemes to obtain accurate and reliable data regarding crop-specific and scheme-level irrigated area coverages. The ground survey was conducted for one irrigation season during the months of January to March 2017.

To understand the spatial attributes of individual heterogeneous and highly fragmented farm plots, it is crucial to employ high resolution imagery. Nowadays, there are multiple sources of high-resolution imagery such as Orbview, Worldview-2, and Quickbird are few examples. However, the availability of such sources in the developing world is limited both temporally and spatially, besides the budgetary constraints. Hence, the use of publicly available Google Earth (Google, Inc.) images have become an emerging and relatively unexploited source of high-resolution images (Knorn et al., 2009; Malarvizhi et al., 2016; Standart et al., 2011).

For this study, therefore, a zoomed-in view of Google Earth images covering the study sites was used to digitize the field boundaries of each farmers' plot $(0.2$ hectares on average). This enabled us to prepare the plotlevel maps of each study sites separately (Figure 2A and B) and exported as a Keyhole Markup Language (KML) file from Google Earth. The digitized maps were converted from (kml) (Keyhole, Inc.) to a shapefile (.SHP) format in ArcGIS 10.1, and printed on A4 size paper to create a paper-based map. 
The paper-based maps coupled with a GPS receiver were then used to match the actual field parcels with the paper-based plots while conducting the field survey. Each field parcel is visually identified by the shape of its polygon on the ground, then the name of the crop being irrigated in each parcel is written in the corresponding paper-based plots (Figure 2C). The crop names on the paper-based map are finally fed to the attribute table of the digitized shapefile map to build a Google Earth (GE)-based crop map of the respective irrigation schemes (Figure 2D).

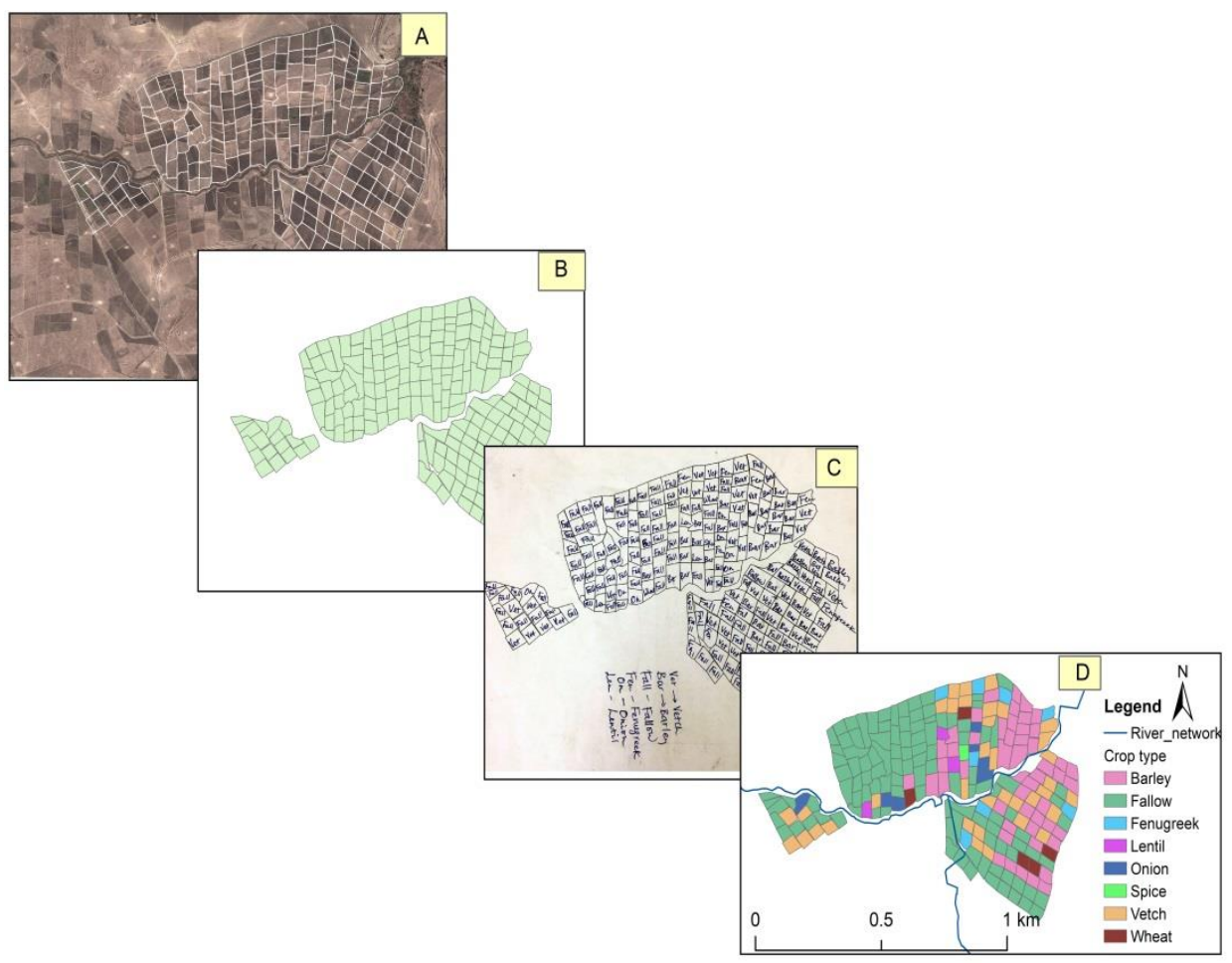

Fig. 2. Procedures followed in developing a cropland map of irrigation schemes A) Google Earth image with digitized land parcels B) Land parcels extracted and analyzed in ArcGIS C) Printed copy of the land parcels and filled during the ground survey D) Final cropland map

\section{LANDSAT-8 Images Acquisition and Selection}

Level-1 LANDSAT-8 OLI (Optical Land Imager) images, for the period from 2013 to 2017, were downloaded from the Earth-Explorer archive of the United States Geological Survey (https://earthexplorer.usgs.gov.). A total of fourteen images were deliberately selected based on their acquisition date and duration of the irrigation season (Table 2). In Tigray region, irrigation usually starts during December/January and ends in May/June. Moreover, the growth stages of crops also affect the accuracy of classification from satellite images. Crops tend to have more canopy cover and look more greenish during the crop-development and mid-season stages or when the canopy cover is around $70-75 \%$ (Brouwer and Heibloem, 1986). For most cereal crops, the crop development stage starts after 20-30 days of planting
(Brouwer and Heibloem, 1986). Therefore, images acquired during the months from January to April were used for this study, except for one season where the only appropriate image was acquired in May. Another exception is that a suitable image could not be found for Shilanat-2 for 2013 irrigation season.

Whenever there was more than one image available for a given site, selection was made based on the amount of cloud cover percentages. Images with zero or minimal cloud coverage were used as much as possible. Furthermore, in cases where two or more images for a given site tend to have comparable cloud cover and acquisition dates, they all get to qualify for preprocessing and classification. Finally, the classified image which appears to give more area of irrigated land, within the limits of the irrigation scheme, was selected for comparison purpose.

Table 2. List of LANDSAT-8 OLI images used according to their acquisition, year, date and irrigation schemes featured.

\begin{tabular}{lrrrrr}
$\begin{array}{l}\text { Irrigation } \\
\text { scheme }\end{array}$ & 2013 & 2014 & 2015 & 2016 & 2017 \\
\hline Haiba & 12-Apr & 7-Mar & 1-May & 4-Apr & 23-Apr \\
Shilanat-2 & NA* & 3-Feb & 6-Feb & 24-Jan & 26-Jan \\
May-nigus & $12-\mathrm{Apr}$ & 26-Feb & 13-Feb & 16-Feb & 7-Apr
\end{tabular}




\section{Image Analysis}

\section{LANDSAT-8 (OLI) Image Preprocessing}

All the downloaded Terrain corrected level1LANDSAT-8 data were preprocessed to normalize the reflectance. First, all the LANDSAT-8 data were detected for the presence of clouds from the metadata file over the specified study sites. For images with minimal cloud cover, the visual examination was made to make sure that the cloud doesn't fall on the study sites. Those LANDSAT- 8 images with cloud cover on the study site were not considered for further analysis. The images were further atmospherically corrected to surface reflectance using the Fast Line-of-sight Atmospheric Analysis of Hypercube (FLAASH) (AdlerGolden et al., 1999) algorithm in ENVI-5.0 software. The details of the procedures followed for preprocessing stage are presented in a flowchart (Figure 3).

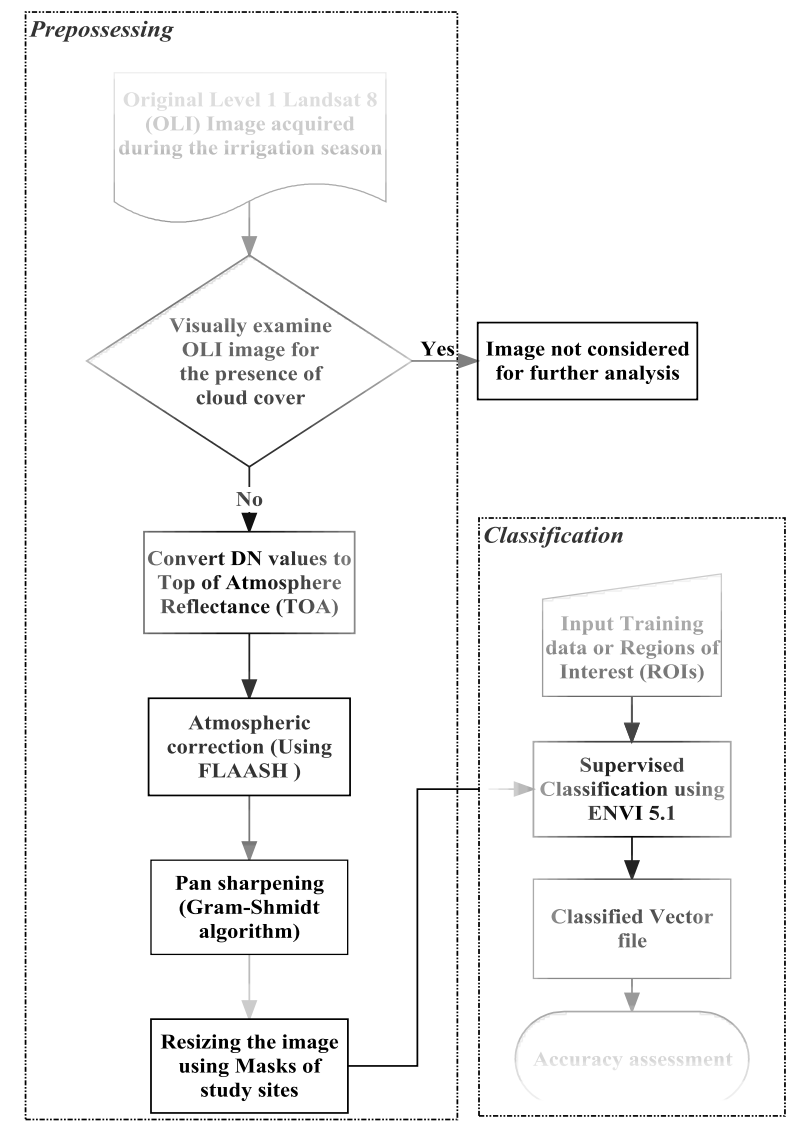

Fig. 3: Flowchart for preprocessing and classification of LANDSAT 8 images.

\section{The Classification Process}

Supervised classification of individual clipped LANDSAT-8 image was carried out using the maximum Likelihood algorithm in-built in ENVI-5.0 (Figure 3). The images were classified into three classes, namely: irrigated, non-irrigated and water bodies (reservoirs). Training areas (Regions of Interest (ROIs)) were collected both using GPS and points extracted from Google Earth. The main purpose of this classification process is to simply estimate the lumped coverage of the irrigated area in a given irrigation season, not to identify the types of crops.

\section{Accuracy Assessment}

Accuracy assessment was conducted by comparing the classified images against a bulk ground truth data collected in 2017 from the field using a simple random sampling approach. Besides the in-situ samples, some ground truth data was collected from zoomed-in Google Earth images. According to Luedeling and Buerkert (2008), Google Earth gives a viable means of assessing the accuracy of land cover classification. Hence, ground truth points which range from 261 to 500 were taken from each scheme for images classified during the 2017 irrigation season. For the years from 2013-2016, ground truth points were extracted from historical records of farm plots. This was done by asking farmers and experts on 50 farmer's plots in each scheme. Confusion matrix was prepared to help calculate the overall accuracy and Kappa coefficients. In addition, class-specific accuracy parameters developed by Velpuri et al. (2009), were also calculated to further validate the accuracy of classification.

\section{Results and Discussion}

\section{Accuracy of classification}

Tables 3a-c present the accuracy parameters derived from the confusion matrix for each scheme and all years (2013-2017) under study. The average overall accuracy of classification ranged from 90-92\%. The kappa coefficients were found to be in the range of $83-84 \%$. The highest overall classification accuracy was $96 \%$ for Haiba (2017) and May-nigus (2015) irrigation schemes. Similarly, the highest kappa coefficient (89\%) was obtained for Haiba (2017) and May-nigus (2015) irrigation scheme. On the other hand, the lowest overall classification accuracy (88\%) for Haiba and May-nigus during the 2014 season..

Table 3a. Accuracy measures of each study site for the five years (2013-2017) under study Haiba

\begin{tabular}{lcccccc}
\hline Accuracy measure & \multicolumn{4}{c}{ Year } & \multicolumn{3}{c}{ Average } \\
\cline { 2 - 6 } & 2013 & 2014 & 2015 & 2016 & 2017 \\
\hline 1. Overall accuracy (\%) & 90 & 88 & 91 & 94 & 96 & 82 \\
2. Kapa coefficient (\%) & 83 & 80 & 80 & 85 & 89 & 83 \\
3. Accuracy of irrigated class (\%) & 91 & 79 & 94 & 89 & 83 & 87 \\
4. Errors of commission (\%) & 5 & 7 & 10 & 3 & 4 & 6 \\
5. Errors of omission (\%) & 5 & 7 & 3 & 0 & 3 & 4 \\
\hline
\end{tabular}


Table 3b. Accuracy measures of each study site for the five years (2013-2017) under study for May-nigus.

\begin{tabular}{lcccccc} 
& \multicolumn{5}{c}{ Year } & Average \\
\cline { 2 - 6 } Accuracy measure & 2013 & 2014 & 2015 & 2016 & 2017 & 90 \\
\hline 1. Overall accuracy (\%) & 91 & 88 & 96 & 91 & 92 & 84 \\
2. Kapa coefficient (\%) & 87 & 81 & 89 & 85 & 80 & 88 \\
3. Accuracy of irrigated class (\%) & 85 & 86 & 97 & 94 & 78 & 10 \\
4. Errors of commission (\%) & 13 & 9 & 14 & 11 & 4 & 7 \\
5. Errors of omission (\%) & 0 & 5 & 3 & 6 & 4 \\
\hline
\end{tabular}

Table 3c. Accuracy measures of each study site for the five years (2013-2017) under study for Shilanat-2.

\begin{tabular}{|c|c|c|c|c|c|c|}
\hline \multirow[b]{2}{*}{ Accuracy measure } & \multicolumn{5}{|c|}{ Year } & \multirow[t]{2}{*}{ Average } \\
\hline & 2013 & 2014 & 2015 & 2016 & 2017 & \\
\hline 1. Overall accuracy (\%) & $* \mathrm{NA}$ & 92 & 92 & 90 & 92 & 92 \\
\hline 2. Kapa coefficient (\%) & $* \mathrm{NA}$ & 86 & 80 & 82 & 83 & 83 \\
\hline 3. Accuracy of irrigated class (\%) & $* N A$ & 95 & 91 & 89 & 90 & 91 \\
\hline 4. Errors of commission (\%) & $* N A$ & 5 & 3 & 4 & 4 & 4 \\
\hline 5. Errors of omission (\%) & $* N A$ & 5 & 9 & 11 & 5 & 8 \\
\hline
\end{tabular}

*NA: Not available.

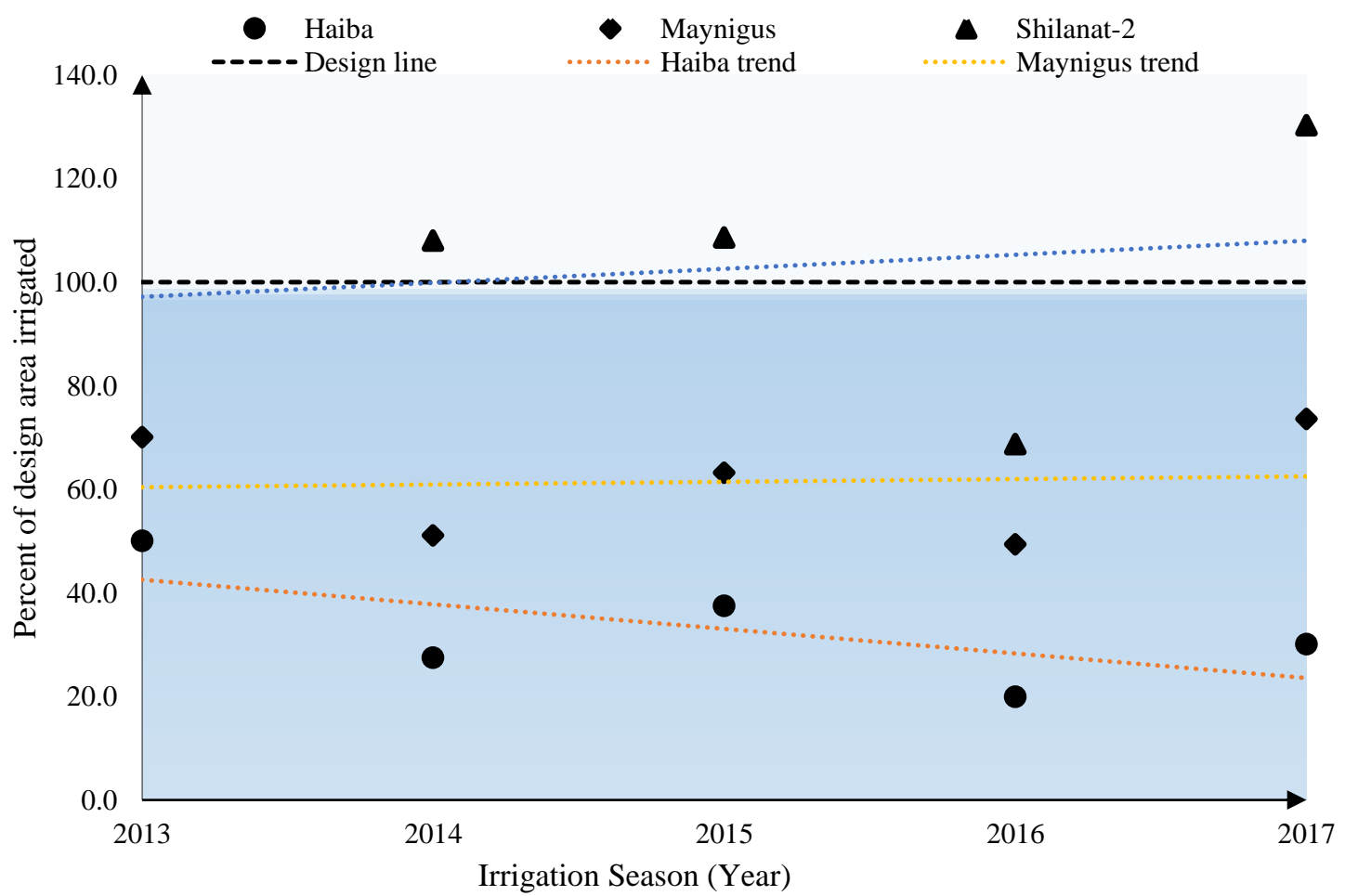

Fig. 4. Trend of the total irrigated area coverages of each site against the design and irrigation seasons (2013-2017).

The accuracy of irrigated classes falls in the range of 78$97 \%$ with the highest (in 2015) and lowest (in 2017) for May-nigus irrigation scheme. Overall accuracy levels of more than $85 \%$ are assumed acceptable in supervised classification from satellite images (Treitz and Rogan, 2004; Yang and Liu, 2005; Esetlili et al., 2018; Alganc1 et al., 2018). Hence, taking the $85 \%$ as the reference, the overall accuracy of all the irrigation schemes was assumed as sufficiently acceptable for further analysis in the next sections.

\section{Trend of Irrigation Area Coverages in Comparison to the Design}

According to the design documents, the three damreservoirs were proposed to irrigate 300 ha, 124 ha and 150 ha for Haiba, May-Nigus, and Shilanat-2, respectively (Table 1). The overall trend in irrigation coverage clearly showed a steady declining pattern for Haiba, increasing trend for Shilanet-2 apart from the fluctuations depending on the availability of rainfall and inflow into the reservoirs every year (Figure 4). When compared to the design, the irrigation coverage ranges from a minimum of $20 \%$ (Haiba) in 2016 to a maximum of $130 \%$ (Shilanat-2) in 2013 of the design irrigable area. The two irrigation schemes (Haiba and May-nigus) were found to irrigate below design (Dashed line) while Shilanat -2 is over performing (Figure 4).

Previous studies indicate that there is an overall belowdesign performance in many of micro-dam irrigation schemes in Tigray regional state (Berhane et al., 2013; Hagos et al., 2016; Oates et al.). In a study on two micro 
dam schemes, Berhane et al. (2017) reported that the actual irrigation coverage was 10 to $50 \%$ of the design command area. This could be attributed to factors such as poor design, low inflow conditions, sedimentation of reservoirs, seepage, poor irrigation land and water management and other socio-economic factors (Abdurahman, 2009; Eyasu, 2005; Yohannes et al., 2017). On the other hand, the results for Shilanat-2 irrigation scheme indacated that there is above-design performance which is due to the tendency of farmers to irrigate low value crops (i.e. such as barley and vetch) with relatively low irriagtion water requiements and thereby maximizing the area irrigated. However, though not previously studied for the schemes in Tigray, the economic returns from such irrigation strategies is expected to be very low.

Figure 5 (a-c) shows a five-year LANDSAT- 8 based seasonal irrigation coverage trend of the three study sites with the exception of a missing one-year data for
Shilanat-2 irrigation scheme. The trend exhibits a variability in irrigated coverage depending on water stored in the reservoir during the respective season within five-year period. The maximum irrigation coverage was observed during the 2013 irrigation season followed by 2017 irrigation season for all schemes. Irrigation coverage in 2016 was at its lowest in all the three irrigation schemes studied. This could be attributed to the 2015/2016 El Nino effect, which resulted in warm climate, low amount of annual rainfall and thereby low inflow into the dam reservoirs (Gleixner et al., 2017). The reduction in irrigated area coverage during the El Nino season compared to the design command area was found to be $31 \%, 50.5 \%$ and $80 \%$ for Shilanat-2, Maynigus and Haiba irrigation schemes, respectively. At a national scale, as a result of the 2015/2016 El Nino, Ethiopia was hit by one of the worst droughts in 50 years (Seaward, 2016). According Negeri (2017) to during this season, the agricultural GDP of Ethiopia was reduced by about $13.59 \%$.
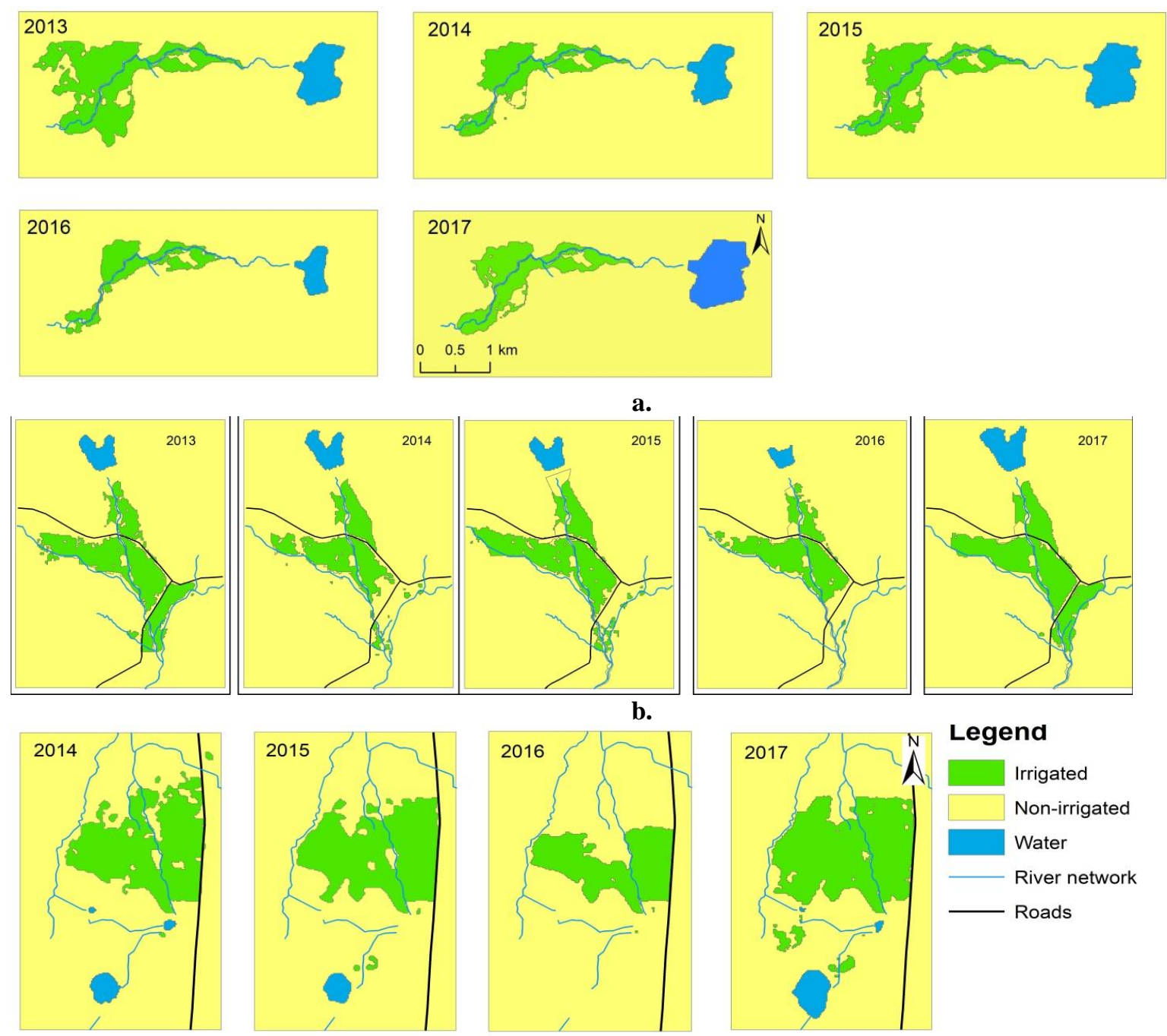

Legend

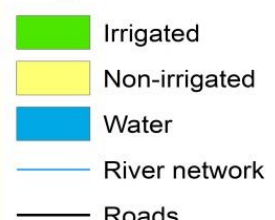

c.

Fig. 5. Trends of irrigation coverage a) Haiba, b) May-Nigus, c) Shilanat-2.

Comparison of LANDSAT-8 Based Estimates with Traditionally Obtained Data

Comparing Scheme-level Area by LANDSAT-8 and traditional estimates (2013-2017)
One way of comparing the traditional estimates with satellite imagery-based estimations is the total area coverage of an irrigated scheme (Table 4). Here, the scheme area estimates of the traditional approach were found to be consistently higher than the LANDSAT- 8 
based estimates in the two irrigation schemes (Maynigus and Haiba) for all years. To the contrary, for Shilanat-2 irrigation scheme, there was underestimation by the traditional method for three years $(2014,2015$ and 2017). The percentage increase of the traditional method over the LANDSAT-8 based estimates ranges from 3\% to $53 \%$ for May-Nigus and $-20 \%$ (underestimation) to 62 $\%$ for Shilanat-2. Extremely higher differences were observed for Haiba irrigation scheme, where the traditional estimates exceed the LANDSAT- 8 based estimates ranging from $20 \%$ (2013) to more than three folds $(224 \%)$ for the 2016 irrigation season. In general, the traditional estimates overestimated almost $80 \%$ of the 14 cases considered. Moreover, the traditional estimates were higher than the LANDSAT- 8 based estimates by more than $100 \%$ for Haiba irrigation scheme. This clearly shows the huge differences in estimates from the two approaches.

Table 4: Differences (percent) in scheme-area estimates of the traditional method against LANDSAT- 8 based estimate (negative results indicate underestimation by the traditional method).

\begin{tabular}{lccccc} 
Irrigation & Year & & & & \\
\cline { 2 - 6 } scheme & 2013 & 2014 & 2015 & 2016 & 2017 \\
\hline Haiba & 20.6 & 122.6 & 100.0 & 224.4 & 163.7 \\
May-Nigus & 15.1 & 53.2 & 25.0 & 25.1 & 3.0 \\
Shilanat-2 & *NA & -20.7 & -2.7 & 63.0 & -3.6 \\
\hline
\end{tabular}

A study by Frolking et al. (1999) conducted at different administrative scales of China found that remote sensing estimates of cropland area, surpassed the national agricultural census data by about 50-100\%. Another LANDSAT-TM based study reported overestimation of the remote sensing estimates by $40 \%$ of the official report on cropland areas. Similarly, other studies (Ajaz et al., 2016; Cai et al., 2017; Crook, 1993; Forkuor et al., 2017; Fritz et al., 2010) also varying extent of overestimation by the remote sensing approaches of estimating cropland area. However, in this study, the remote sensing estimates are lower than the traditional estimates for majority of the sites and seasons, unlike many of the results obtained from previous studies, where remote sensing estimates are larger than census data. Hence, given the poor data collection and reporting of agricultural data in Ethiopia (Mandefro, 2016), the results put the reliability of traditional estimates under question.

\section{Comparing the Traditional, LANDSAT-8 based and} GE-based Area Estimates for 2017.

The area estimates from the two approaches were compared against (Google Earth) GE-based estimates conducted in 2016/17 season (Figure 6).
The GE-based estimates are taken as a reference value because they are based on plot-by-plot extensive field survey. The result showed that, compared to the GEbased estimates, the LANDSAT- 8 based results were overestimated by $1.8 \%, 9 \%$ and $16 \%$ for Shilanat- 2 , May-Nigus and Haiba, respectively. Other study by Ghebreamlak et al. (2018) compared remote sensing (LANDSAT-7 ETM+) estimates of irrigated area with field collected data from five irrigation blocks in the Gash delta of Sudan and obtained differences ranging from $20 \%$ (overestimation) to $-25 \%$ (underestimation).

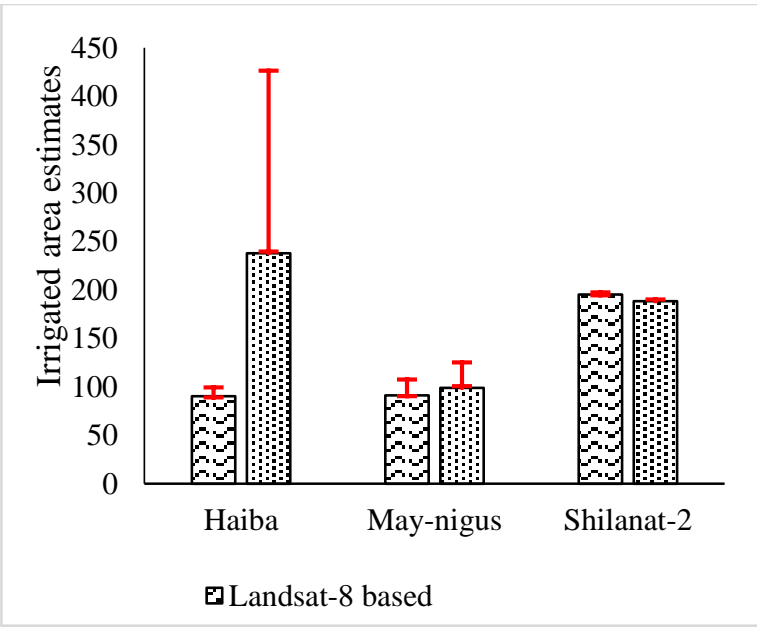

Fig. 6. Discrepancies (in error bars) of LANDSAT-8 based and traditional estimates compared to GE-based estimates.

For the traditional method, the discrepancies in Shilanat2 is $-1.8 \%$, indicating a slight underestimation. However, for May nigus and Haiba, the discrepancy levels are 26\% and $238 \%$, respectively. The discrepancies against the GE-based estimates of the traditional method are by far higher for the two schemes. This is another indicator that traditional estimates might have exaggerated figures in estimating the total irrigated area in the scheme.

\section{Comparing Crop-Areas by the Traditional Estimate and GE-based Field survey}

The crop-areas obtained from traditional census were also compared against GE-based field survey for the year 2017.The results obtained are shown in a scatter-gram (Figure $7 \mathrm{a}$ to $\mathrm{c}$ ). The traditional estimates tend to overestimate the crop areas as compared to the GE-based estimates for Haiba scheme, and majority of large area crops for Shilanat and May-nigus scheme. 

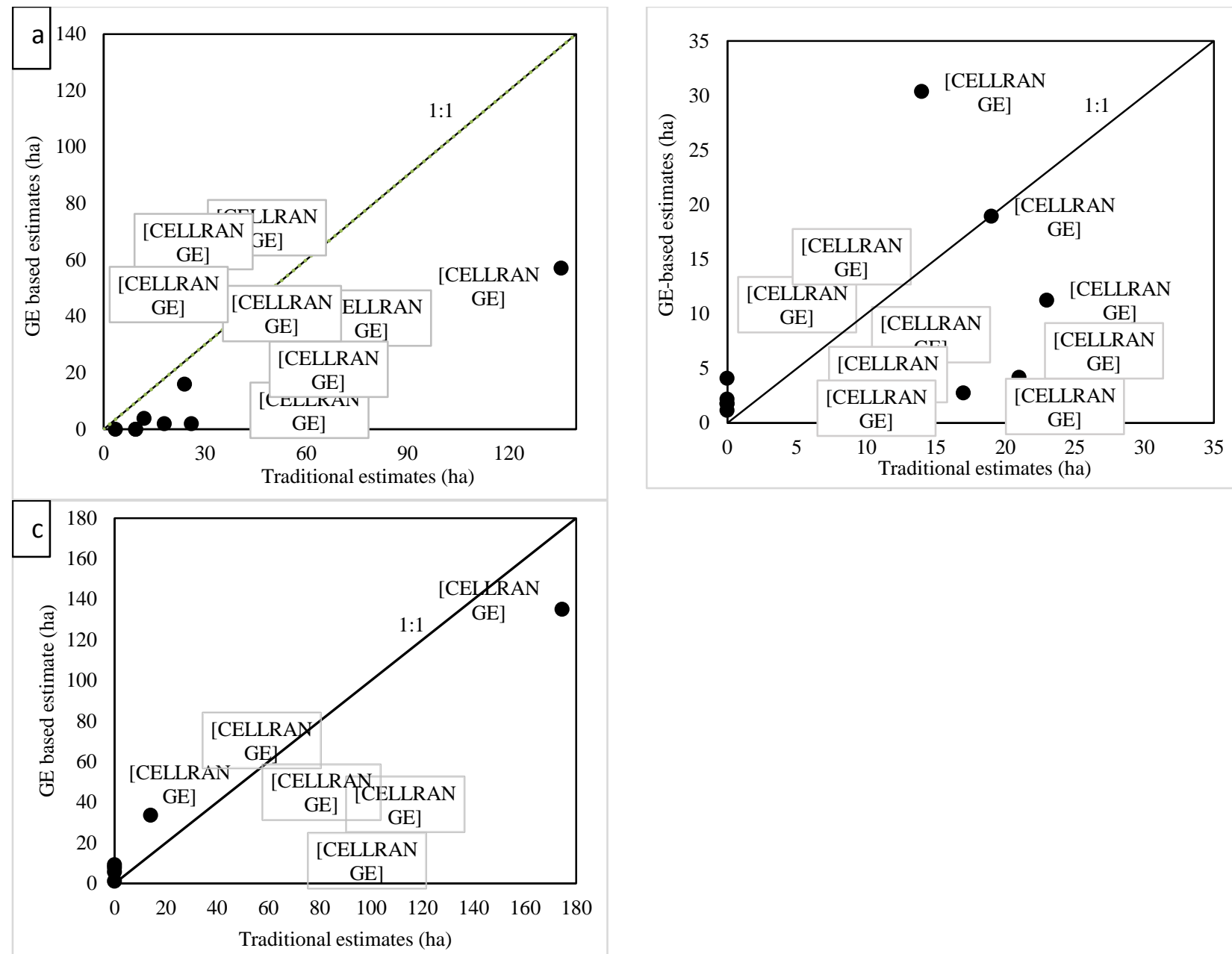

Fig. 7 Crop-wise comparison between traditional and GE-based estimates for a) Haiba b) Maynigus and c) Shilanat-2 irrigation schemes

The traditional estimates missed to capture crops with small area coverages, i.e. crop areas less than 2.5 ha and 10ha for Haiba and Shilanat schemes, respectively. On the other hand, traditional estimates tend to overestimate crops with relatively larger area coverages in all the scheme except one case (maize crop) in May-nigus scheme. Overall, there is no clear trend on the on the estimates of crop area by the traditional method for all the schemes.

Moreover, some of the crops were not documented for May-nigus scheme while extraneous crops were added in Shilanat and Haiba schemes. As shown in Table 5, only $33 \%$ crops were documented by the traditional estimation for Shilanat-2 scheme. The rest of the crops are probably failed to be accounted assuming that they have negligible area by the data collectors, though they actually have a lumped areal coverage of more than $12 \%$ of the scheme irrigated area during the season. Similarly, only half of the crops were recognized for May-nigus scheme. On the other hand, the traditionally documented number of crops for Haiba are by $50 \%$ more than the actual number of crops irrigated (Table 5). This is possibly due to experts not doing enough inventory in the field leading to fabricated number of crops and their coverage.
Table 5. Comparison by the number of crops recognized or missed by the traditional and GE-based field survey estimates

\begin{tabular}{llll}
\hline Scheme & $\begin{array}{l}\text { Actual } \\
\text { number } \\
\text { of crops } \\
\text { irrigated } \\
\text { (GE } \\
\text { based } \\
\text { field } \\
\text { survey) }\end{array}$ & $\begin{array}{l}\text { Number of } \\
\text { crops } \\
\text { recognized } \\
\text { by the } \\
\text { traditional } \\
\text { approach }\end{array}$ & $\begin{array}{l}\text { Percentage of } \\
\text { crops } \\
\text { recognized/over- } \\
\text { reported crops } \\
(\%)\end{array}$ \\
& 6 & 9 & $150^{*}$ \\
\hline $\begin{array}{l}\text { Haiba } \\
\text { Nigus }\end{array}$ & 10 & 5 & 50 \\
$\begin{array}{l}\text { Shilanat-2 } \\
\text { * }\end{array}$ & $\mathbf{2}$ & $\mathbf{3 3 . 3}$ \\
more number crops than that actual number during that \\
season.
\end{tabular}

\section{Conclusion}

In this study, high resolution (Google Earth) and medium resolution (LANDSAT-8) image were employed to determine the discrepancies in traditional estimates of irrigated area coverage in three irrigation schemes found in Northern Ethiopia, Tigray Regional state. Given that the uncertainties and setbacks 
associated with remotely sensed data, and spatially and temporally variable nature of irrigated fields it may be difficult to say remote-sensing based estimates of irrigated area coverages are accurate and flawless. However, remote sensing images have proved to be good at providing indicative values with significant accuracies. Moreover, in this study, appreciable classification accuracies were obtained when compared to GE-based estimates. The overall results indicate that there are wide-spread inconsistencies in the traditional reports regarding the total irrigated coverage, number and area of crops irrigated in a given scheme. Thus, due attention should be given to the existing method of data collection and reporting of area extents of schemes and Otherwise, as the results indicate, if things go as is, it will have grave consequences in the National Gross Domestic Product (GDP) and other economic variables. In addition, it also has a misleading role towards international funding organizations such as the International Monetary Fund (IMF) and World Bank by providing inconsistent and exaggerated agricultural reports. In developing countries like Ethiopia, in compliance to the size and homogeneity of irrigation schemes, the use of high and medium and high resolution could have a great role in improving the reliability of data figures from irrigated agriculture.

\section{Acknowledgements}

This study was funded by Mekelle University under the Recurrent Budget scheme. The authors would like to thank Mekelle University for providing financial and facilities support to conduct this research. The experts and professionals who work at District and Kebelle level Agriculture and Rural Development (ARD) offices are also acknowledged for providing secondary data. The authors want to thank the anonymous reviewers for their valuable comments and recommendations.

\section{The authors declare no conflict of interest.}

\section{References}

Abdurahman, M. A. (2009). Assessment of micro-dam irrigation projects and runoff predictions for ungauged catchments in Northern Ethiopia 2009. (PhD dissertation), Universität Münster, Münster, Germany.

Addis, K. (2009). Drought and famine: Ethiopia's vicious cycle continues. Time Magazine, 15, Addis Ababa, Ethiopia.

Adler-Golden, S., Matthew, M., Bernstein, L., Levine, R., Berk, A., Richtsmeier, S., . . . Burke, H.-h. (1999). Atmospheric correction for shortwave spectral imagery based on MODTRAN4 (Vol. 3753), SPIE, Denver, USA.

Ajaz, A., Karimi, P., de Fraiture, C., and Xueliang, C. (2016). National and global censuses or satellitebased estimates? Asia's irrigated areas: In a muddle. Paper presented at the Proceedings of the 2nd World Irrigation Forum, Chiang Mai, Thailand.

Alganc1, U., Sertel, E., Kaya, Ş. (2018). Determination of the Olive Trees with Object Based Classification of Pleiades Satellite Image. International Journal of Environment and Geoinformatics, 5(2), 132-139. DOI: $10.30897 /$ ijegeo.396713.

Ambika, A. K., Wardlow, B. D., and Mishra, V. (2016). Data descriptor: Remotely sensed high resolution irrigated area mapping in india for 2000 to 2015 . Scientific data, 3(1), 1-14.

AQUASTAT. (2015). Country fact sheet: Ethiopia. FAO, Rome, Italy.

Awulachew, S. B., Yilma, A. D., Loulseged, M., Loiskandl, W., Ayana, M., and Alamirew, T. (2007). Water resources and irrigation development in Ethiopia (Vol. Working Paper 123), International Water Management Institute (IWMI), Srilanka, Colombo.

Behailu, M., Tadesse, N., Legesse, A., and Teklu, D. (2004). Community based irrigation management in the Tekeze basin: Performance evaluation of small scale irrigation schemes. Unpublished work.

Berhane, G., Amare, M., Gebreyohannes, T., and Walraevens, K. (2017). Geological and geophysical investigation of water leakage from two micro-dam reservoirs: Implications for future site selection, northern Ethiopia. Journal of African Earth Sciences, 129, 82-93.

Berhane, G., Martens, K., Al Farrah, N., and Walraevens, K. (2013). Water leakage investigation of micro-dam reservoirs in Mesozoic sedimentary sequences in Northern Ethiopia. Journal of African Earth Sciences, 79, 98-110.

Bewket, W., and Conway, D. (2007). A note on the temporal and spatial variability of rainfall in the drought- prone Amhara region of Ethiopia. International Journal of Climatology: A Journal of the Royal Meteorological Society, 27(11), 14671477.

Biggs, T. W., Thenkabail, P. S., Gumma, M. K., Scott, C. A., Parthasaradhi, G. R., and Turral, H. N. (2006). Irrigated area mapping in heterogeneous landscapes with MODIS time series, ground truth and census data, Krishna Basin, India. International Journal of Remote Sensing, 27(19), 4245-4266.

Brouwer, C., and Heibloem, M. (1986). Irrigation water management: Irrigation water needs. Training manual, 3.

Cai, X., Magidi, J., Nhamo, L., and van Koppen, B. (2017). Mapping irrigated areas in the Limpopo Province, South Africa (Vol. 172), International Water Management Institute (IWMI).

Carletto, C., Jolliffe, D., and Banerjee, R. (2013). The Emperor has no data! Agricultural statistics in subSaharan Africa World Bank Working Paper, Washington, DC.

Crook, F. W. (1993). Underreporting of China's cultivated land area: Implications for world agricultural trade. China International Agricultural and Trade Report, 33-39.

CSA, C. S. A. (2018). Key Findings of the 2017/2018 (2010 EC) Agricultural Sample Survey. Addis Ababa.

Esetlili, M., Bektas Balcik, F., Balik Sanli, F., Kalkan, K., Ustuner, M., Goksel, Ç., Gazioğlu, C., Kurucu, Y. (2018). Comparison of Object and Pixel-Based 
Classifications For Mapping Crops Using Rapideye Imagery: A Case Study Of Menemen Plain, Turkey. International Journal of Environment and Geoinformatics, 5(2), 231-243. DOI: 10.30897/ijegeo.442002.

Eyasu, Y. (2005). Development and management of irrigated lands in Tigray, Ethiopia, Balkema, Delft, The Netherlands.

FAO. (1996). The State of Food and Agriculture. Roma, Italy.

FAO. (2008). The Agricultural Bulletin Board on Data Collection, Dissemination and Quality of Statistics.

FAO. (2012). FAO statistical yearbook. Rome, Italy.

Filmon, T. G. (2013). Evaluation of the Water Resources Potential of the Shilanat Watershed Using the Water Balance Method, Tigray, Northern Ethiopia. (M.Sc. thesis), Haramaya University, Ethiopia, Haramaya.

Forkuor, G., Conrad, C., Thiel, M., Zoungrana, B. J.-B., and Tondoh, J. E. (2017). Multiscale Remote Sensing to Map the Spatial Distribution and Extent of Cropland in the Sudanian Savanna of West Africa. Remote Sensing, 9(8), 839.

Fritz, S., See, L., and Rembold, F. (2010). Comparison of global and regional land cover maps with statistical information for the agricultural domain in Africa. International Journal of Remote Sensing, 31(9), 2237-2256.

Frolking, S., Xiao, X., Zhuang, Y., Salas, W., and Li, C. (1999). Agricultural land-use in China: a comparison of area estimates from ground-based census and satellite-borne remote sensing. Global Ecology and Biogeography, 8(5), 407-416.

Gebregziabher, G., Namara, R. E., and Holden, S. (2012). Technical Efficiency of Irrigated and RainFed Smallholder Agriculture in Tigray, Ethiopia: A Comparative Stochastic Frontier Production Function Analysis. 51, 203-226.

Ghebreamlak, A., Tanakamaru, H., Tada, A., Ahmed Adam, B., and Elamin, K. (2018). Satellite-Based Mapping of Cultivated Area in Gash Delta Spate Irrigation System, Sudan. Remote Sensing, 10(2), 186.

Giordano, M. (2009). Global Groundwater? Issues and Solutions. Annual Review of Environment and Resources, 34(1), 153-178.

Gleixner, S., Keenlyside, N., Viste, E., and Korecha, D. (2017). The El Niño effect on Ethiopian summer rainfall. Climate Dynamics, 49(5), 1865-1883.

Gumma, M. K., Mohanty, S., Nelson, A., Arnel, R., Mohammed, I. A., and Das, S. R. (2015). Remote sensing based change analysis of rice environments in Odisha, India. Journal of Environmental Management, 148, 31-41.

Hagos, E. Y., Schultz, B., and Depeweg, H. (2016). Reservoir Operation in View of Effective Utilization of Limited Water in Semi-Arid Areas The Case of Gumsalasa Earthen Dam Irrigation Scheme in Tigray, Ethiopia. Irrigation and Drainage, 65(3), 294-307.

Heller, E., Rhemtulla, J. M., Lele, S., Kalacska, M., Badiger, S., Sengupta, R., and Ramankutty, N. (2012). Mapping crop types, irrigated areas, and cropping intensities in heterogeneous landscapes of
Southern India using multi-temporal mediumresolution imagery. Photogrammetric Engineering and Remote Sensing, 78(8), 815-827.

IMF. (2016). Article IV Consultation-Press Release; Staff Report; and Statement by the Executive Director for The Federal Democratic Republic of Ethiopia (IMF Country Report No. 16/322). Washington, D.C.

İmamoğlu, M., Sertel, E. (2016). Analysis of Different Interpolation Methods for Soil Moisture Mapping Using Field Measurements and Remotely Sensed Data. International Journal of Environment and Geoinformatics, 3(3), 11-25. DOI: 10.30897/ijegeo.306477.

Jacobson, A., Dhanota, J., Godfrey, J., Jacobson, H., Rossman, Z., Stanish, A., . . . Riggio, J. (2015). A novel approach to mapping land conversion using Google Earth with an application to East Africa. Environmental Modelling and Software, 72, 1-9.

Kedirkan, N. (2019). Water surface Changes of Lakes in the Central Rift Valley of Ethiopia. International Journal of Environment and Geoinformatics, 6(3), 264-267. DOI: 10.30897/ijegeo.544770.

Knorn, J., Rabe, A., Radeloff, V. C., Kuemmerle, T., Kozak, J., and Hostert, P. (2009). Land cover mapping of large areas using chain classification of neighboring LANDSAT satellite images. Remote Sensing of Environment, 113(5), 957-964.

Luedeling, E., and Buerkert, A. (2008). Typology of oases in northern Oman based on LANDSAT and SRTM imagery and geological survey data. Remote Sensing of Environment, 112(3), 1181-1195.

Malarvizhi, K., Kumar, S. V., and Porchelvan, P. (2016). Use of High Resolution Google Earth Satellite Imagery in Landuse Map Preparation for Urban Related Applications. Procedia Technology, 24, 1835-1842.

Mandefro, H. (2016). Politics by numbers: poverty reduction discourse, contestations and regime legitimacy in Ethiopia. International Review of Sociology, 26(3), 386-406.

MOFED. (2010). Ethiopia: 2010 MDGs Report: Trends and Prospects for Meeting MDGs by 2015.

Murthy Reddi, V. R., Gumma, M. K., Pyla, K. R., Eadara, A., and Gummapu, J. S. (2017). Monitoring Changes in Croplands Due to Water Stress in the Krishna River Basin Using Temporal Satellite Imagery. Land, 6(4), 72.

Nata, T. T., Tafesse, N. T., Kidanu, S. T., and Demo, M. T. (2010). The water balance of may nugus catchment, Tigray, Northern Ethiopia. Agricultural Engineering International: CIGR Journal, 12(1).

Negeri, M. B. (2017). The Effects of El Nino on Agricultural GDP of Ethiopia. American Journal of Water Science and Engineering, 3(4), 45-49.

Nickum, J. E. (2003). Irrigated Area Figures as Bureaucratic Construction of Knowledge: The Case of China. International Journal of Water Resources Development, 19(2), 249-262.

Oates, N., Hisberg, A., Rodríguez Ros, J., Solomon, H., Ludi, E., Marlet, S., and Jamin, J.-Y. (2018). The Implications of State Intervention for Self-Governed 
Irrigation Schemes: Insights From Tigray, Ethiopia. Irrigation and Drainage.

Ozdogan, M., Yang, Y., Allez, G., and Cervantes, C. (2010). Remote Sensing of Irrigated Agriculture: Opportunities and Challenges. Remote Sensing, 2(9), 2274-2304.

Pandey, B., and Seto, K. C. (2015). Urbanization and agricultural land loss in India: Comparing satellite estimates with census data. Journal of Environmental Management, 148, 53-66.

Seaward, C. (2016). El Niño in Ethiopia: Programme observations on the impact of the Ethiopia drought and recommendations for action, Oxfam International.

Standart, G. D., Stulken, K. R., Zhang, X., and Zong, Z. L. (2011). Geospatial visualization of global satellite images with Vis-EROS. Environmental Modelling and Software, 26(7), 980-982.

Thenkabail, P. S., Biradar, C. M., Noojipady, P., Dheeravath, V., Li, Y., Velpuri, M., . . . Dutta, R. (2009). Global irrigated area map (GIAM), derived from remote sensing, for the end of the last millennium. International Journal of Remote Sensing, 30(14), 3679-3733.

Treitz, P., and Rogan, J. (2004). Remote sensing for mapping and monitoring land-cover and land-use change - an introduction. Progress in planning, 61(4), 269-279.

Ülker, D., Ergüven, O., Gazioğlu, C. (2018). Socioeconomic impacts in a Changing Climate: Case Study Syria. International Journal of Environment and Geoinformatics, 5(1), 84-93. DOI: 10.30897/ijegeo.406273.

Velpuri, N., Thenkabail, P. S., Gumma, M. K., Biradar, C., Dheeravath, V., Noojipady, P., and Yuanjie, L. (2009). Influence of resolution in irrigated area mapping and area estimation. Photogrammetric Engineering and Remote Sensing, 75(12), 13831395.

World_Bank. ( 2017). World Development Indicators: population dynamics.

Yang, X., and Liu, Z. (2005). Using satellite imagery and GIS for land- use and land- cover change mapping in an estuarine watershed. International Journal of Remote Sensing, 26(23), 5275-5296.

Yohannes, D. F., Ritsema, C., Solomon, H., Froebrich, J., and van Dam, J. (2017). Irrigation water management: Farmers' practices, perceptions and adaptations at Gumselassa irrigation scheme, North Ethiopia. Agricultural water management, 191, 1628. 